\title{
PENGEMBANGAN KAPASITAS MASYARAKAT DALAM MENGGUNAKAN HANJELI SEBAGAI ALTERNATIF PENGGANTI BERAS SEBAGAI PANGAN POKOK DAN PRODUK OLAHAN
}

\author{
OLEH: \\ IMAS SITI SETIASIH ${ }^{1}$, MEILANNY BUDIARTI SANTOSO ${ }^{2}$, IN-IN HANIDAH ${ }^{3}$, HERLINA MARTA ${ }^{4}$ \\ 1. Pusat Studi Pengembangan Teknologi Pertanian Fakultas Teknologi Industri Pertanian Universitas Padjadjaran \\ 2. Pusat Studi Kewirausahaan Sosial, CSR, dan Pengembangan Masyarakat Fakultas IImu Sosial dan IImu Politik Universitas Padjadjaran \\ 3. Pusat Studi Pengembangan Teknologi Pertanian Fakultas Teknologi Industri Pertanian Universitas Padjadjaran \\ 4. Pusat Studi Pengembangan Teknologi Pertanian Fakultas Teknologi Industri Pertanian Universitas Padjadjaran
}

Email:

(iimdarajat@yahoo.com ${ }^{1}$, meilannybudiarti13@gmail.com ${ }^{2}$, pinkyhanidah@yahoo.com ${ }^{3}$, elyne_marta@yahoo.com ${ }^{4}$

\begin{abstract}
Abstrak
Sering kali kita dengar ungkapan: "Kalo belum makan nasi, yaa belum makan", sebagai ungkapan yang seringkali disampaikan oleh masyarakat di pulau Jawa. Ungkapan tersebut menggambarkan begitu lekatnya kebutuhan warga masyarakat di pulau Jawa terhadap ketersediaan beras sebagai bahan makanan pokok. Peningkatan pengetahuan dasar masyarakat mengenai bahan pangan pokok selain beras merupakan pengantar untuk mengurangi ketergantungan konsumsi beras dan dapat mengaplikasikannya menjadi berbagai produk olahan non-terigu dengan memanfaatkan tepung lokal. Tanaman hanjeli memiliki kekhasan tersendiri, yaitu sebagai tanaman yang membutuhkan lebih sedikit air apabila dibandingkan dengan tanaman padi sawah. Hal ini menunjukkan bahwa hanjeli memiliki peluang besar untuk dikembangkan budidayanya di wilayah desa Karangasem dan Manggungan kecamatan Terisi. Metode yang dilakukan pada kegiatan ini adalah andragogi, yang mensyaratkan peserta pelatihan diposisikan sebagai orang dewasa dan didorong untuk berperan aktif dalam setiap tahapan pelatihan, penyuluhan, dan pendampingan membuat berbagai macam olahan pangan dari tepung hanjeli. Berdasarkan hasil penelitian pada tahun 2015, biji hanjeli memiliki kandungan kadar air 11,46\%, karbohidrat 74,36\%, protein 12,26\%, abu $0,65 \%$ dan lemak 1,28\%. Komposisi kimia pada biji hanjeli menunjukkan bahwa hanjeli dapat dijadikan sebagai bahan pangan pengganti makanan pokok. Hasil pelatihan menunjukkan bahwa tepung tepung hanjeli, dapat digunakan sebagai bahan diversifikasi pangan olahan pengganti tepung terigu untuk produk kue kering, cake, brownies, dan mie.
\end{abstract}

Kata kunci: diversifikasi, beras, hanjeli, karangasem, singkong.

\section{Abstract}

"If we have not eaten rice yet, we do not eat anything", is a kind of phrase that mostly used by people in Java Island, Indonesia. The phrase describes that rice is a primary need as a staple food for the society in Java Island. The increasing knowledge related to other staple food than rice can be a strategy to reduce the dependence of rice consumption in the society and can be applied to make other wheat-free foods by using local flour. Hanjeli plant has its own characteristic in which need 
less water compared to rice plant. This indicates that Hanjeli has a great opportunity to develop its cultivation in the area of Karangasem and Manggungan village, Terisi sub district. The method used in this activity is andragogy in which requires the trainees to be treated as an adult and encouraged to take an active role in every single stage of the training, counseling and mentoring as aimed to make various kinds of food made of Hanjeli flour. Based on the result of the research in 2015, Hanjeli seeds contain $11.46 \%$ water, $74.36 \%$ carbohydrates, $12.26 \%$ protein, $0.65 \%$ ash, and $1.28 \%$ fat. The chemical composition of Hanjeli seeds indicates that Hanjeli can substitute for staple food. The result of the training shows that Hanjeli flour can be used as diversified food ingredients that can substitute for wheat flour to make cookies, cakes, brownies, and noodles.

Key words: Diversification, rice, hanjeli, karangasem, cassava.

\section{Pendahuluan}

Sering kali kita dengar ungkapan: "Kalo belum makan nasi, yaa belum makan", sebagai ungkapan yang seringkali disampaikan oleh masyarakat di pulau Jawa. Ungkapan tersebut menggambarkan begitu lekatnya kebutuhan warga masyarakat di pulau Jawa terhadap ketersediaan beras sebagai bahan makanan pokok.

Kabupaten Indramayu adalah daerah penghasil beras di Jawa Barat, begitupun dengan wilayah desa Karangasem dan Manggungan kecamatan Terisi yang mayoritas masyarakatnya bermata pencaharian sebagai petani dengan komoditas utama padi sawah. Namun, dalam lima tahun terakhir terjadi penurunan hasil padi sebesar \pm 2 ton/ha/tahun. Hal ini diperkirakan terjadi akibat pergantian musim, sehingga timbul masalah kekeringan atau kemarau panjang yang secara signifikan memunculkan cekaman kekeringan serta menghambat segala kegiatan pertanian. Di kedua desa tersebut tersedia irigasi teknis yang mampu mengairi kurang lebih 4,8 ha, dan sisanya masih mengandalkan air hujan. Dengan demikian, apabila masyarakat hanya mengandalkan beras sebagai bahan pangan pokok, maka kondisi kekeringan akan menjadi ancaman bagi masyarakat setempat khususnya.

Kebutuhan masyarakat terhadap beras sebagai bahan makanan pokok lambat laun namun pasti akan menjadi permasalahan serius apabila tidak dibarengi oleh ketersediaan beras di tengah masyarakat. Tentunya hal ini mengingat situasi dan kondisi alam yang terus berubah dan tidak kondusif, sehingga menyebabkan ketersediaan beras menjadi semakin berkurang. Dalam situasi demikian, upaya peningkatan kapasitas masyarakat, baik itu berupa peningkatan pengetahuan maupun keterampilan masyarakat mengenai komoditas pangan pokok selain padi sangat diperlukan untuk memupuk ketahanan pangan masyarakat agar tidak terlalu bergantung pada ketersediaan beras sebagai bahan pangan pokok selama ini.

Seperti halnya di berbagai daerah lain di Indonesia, kabupaten Indramayu memiliki potensi tanaman bahan makanan pokok selain beras, yaitu antara lain tanaman hanjeli, singkong, ubi jalar kuning, jagung dan tanaman palawija lainnya. Tentunya ketersediaan berbagai jenis tanaman tersebut sangat berpotensi untuk dijadikan sebagai bahan pangan alternatif selain beras sebagai bahan makanan pokok bagi masyarakat di pulau Jawa khususnya.

Dari berbagai jenis tanaman alternatif tersebut, khususnya tanaman hanjeli dinilai sangat cocok untuk dibudidayakan di wilayah kabupaten Indramayu (hal ini sejalan dengan analisis situasi di wilayah kabupaten Indramayu) apabila dibandingkan dengan berbagai jenis tanaman palawija lainnya. Tanaman hanjeli memiliki kekhasan tersendiri, yaitu sebagai tanaman yang membutuhkan 
lebih sedikit air apabila dibandingkan dengan tanaman padi sawah. Berdasarkan hasil penelitian pada tahun 2015, biji hanjeli memiliki kandungan kadar air 11,46\%, karbohidrat $74,36 \%$, protein $12,26 \%$, abu 0,65 $\%$ dan lemak $1,28 \%$. Komposisi kimia pada biji hanjeli menunjukkan bahwa hanjeli dapat dijadikan sebagai bahan pangan pengganti makanan pokok.

Biji hanjeli selain digunakan sebagai sumber karbohidrat, juga dapat digunakan dalam pengobatan khususnya Chinesse medicines. Berdasarkan beberapa hasil penelitian, baik secara in vitro maupun in vivo menunjukkan bahwa hanjeli merupakan sumber komponen bioaktif yang memiliki aktivitas sebagai antioksidan, antikanker, hipolipidemik dan antiradang. Komposisi kimia dan karakteristik yang bermanfaat bagi kesehatan ditemukan berbeda secara signifikan diantara berbagai fraksi penggilingan, sehingga disimpulkan bahwa penanganan pasca panen dan proses pengolahan yang dilakukan sangat berpengaruh pada kandungan komponen bioaktif pada bahan pangan hasil olahan hanjeli (Hao dan Yu, 2012).

Di samping sebagai pangan pengganti beras, tepung hanjeli dapat diaplikasikan pada berbagai pangan olahan sebagai bahan pengganti tepung terigu seperti cookies, biskuit, brownies, bihun, cake, dan produk pangan olahan lainnya. Adapun berbagai jenis tanaman palawija lainnya sudah sangat biasa dimanfaatkan oleh masyarakat sebagai sumber karbohidrat selain beras, walaupun dalam pengolahannya belum banyak variasi olahan yang dihasilkan.

Selain analisis terhadap berbagai jenis potensi tanaman sumber karbohidrat selain beras, upaya peningkatan pengetahuan masyarakat terkait cara untuk melakukan berbagai teknik pengolahan yang tepat terhadap berbagai jenis alternatif pangan non beras pun sangat diperlukan, sehingga ketersediaan bahan pangan akan dibarengi oleh peningkatan kapasitas masyarakat dalam mengolahnya dan dalam jangka panjang diharapkan dapat meningkatkan pendapatan masyarakat dan bahkan meningkatkan angka pendapatan daerah.

\section{Metode}

Metode yang dilakukan pada kegiatan ini adalah penyuluhan, pelatihan dan pendampingan membuat berbagai macam olahan pangan dari tepung hanjeli, tepung singkong, dan tepung ubi jalar kuning. Dalam pelaksanaan pelatihan, digunakan metodologi pelatihan andragogi, yang mensyaratkan peserta pelatihan diposisikan sebagai orang dewasa dan didorong untuk berperan aktif dalam setiap tahapan pelatihan. Baik melalui metode brainstrorming mengenai permasalahan yang dihadapi dan juga metode sharing terkait pengalaman di antara sesama peserta pelatihan dan juga dari fasilitator pelatihan. Hal ini bertujuan agar peserta pelatihan dapat melihat segala sesuatu terkait dengan permasalahan yang sedang dihadapi dari sudut pandang yang berbeda.

\section{Pembahasan}

Pengembangan kapasitas dapat diartikan sebagai upaya memperkuat kapasitas individu, kelompok atau organisasi yang dicerminkan melalui pengembangan kemampuan, keterampilan, potensi dan bakat serta penguasaan kompetensi-kompetensi, sehingga individu, kelompok atau organisasi dapat bertahan dan mampu mengatasi tantangan perubahan yang terjadi secara cepat dan tidak terduga. Pengembangan kapasitas dapat pula dimaknai sebagai proses kreatif dalam mengembangkan kemampuan yang sudah ada ataupun membangun kapasitas yang belum nampak.

T. Nill dan C. Mindrum (2001) menyatakan pengembangan kapasitas merupakan istilah yang digunakan untuk membangun suatu masyarakat melalui perubahan pada dirinya, misalnya peningkatan ilmu pengetahuan, skill, pengorganisasian program dan lain sebagainya.

Ann Philbin mendefinisikan pengembangan kapasitas sebagai berikut: 


\begin{tabular}{|c|c|c|c|c|}
\hline Jurnal Penelitian \& PKM & Juli 2017 & Vol 4, No: 2 & Hal: $129-389$ & $\begin{array}{c}\text { ISSN } \\
2442-448 X(p), 2581-1126(e)\end{array}$ \\
\hline
\end{tabular}

Capacity building is defined as the "prosess of developing and strengthening the skills, instincts, abilities, processes and resources that organizations and communities need to survive, adapt, and thrive in the fastchanging world." (Philbin, 1996)

Berdasarkan pernyataan di atas, Ann
Philbon berusahar mendefinisikan pengembangan kapasitas atau pengembangan kapasitas sebagai proses mengembangkan dan meningkatkan keterampilan, bakat, kemampuan sumber daya organisasi sebagai kebutuhan untuk bertahan, menyesuaikan diri dan menumbuhkan organisasi di era perubahan yang cepat.

Pengembangan kapasitas dapat juga didefinisikan sebagai sebuah proses untuk:

1. Meningkatkan kemampuan individu, kelompok-kelompok, organisasiorganisasi dan juga masyarakat untuk menganalisa lingkungan mereka

2. Mengenali masalah-masalah, kepentingan-kepentingan dan kesempatan-kesempatan

3. Merumuskan strategi-strategi untuk menyelesaikan masalah-masalah dan kepentingan-kepentingan tersebut di atas serta untuk meraih kesempatankesempatan yang relevan

4. Merancang sebuah rencana untuk program-program

5. Memanfaatkan secara efektif sumbersumber dasa yang mendukunga pelaksanaannya, memantau dan mengevaluasi rencana programprogram

6. Menggunakan arus balik untuk mempelajari pelajaran-pelajaran

Dalam kegiatan pengembangan kapasitas masyarakat untuk menggunakan bahan tepung selain beras sebagai alternatif pangan olahan, proses pengembangan kapasitas dilakukan dengan melalui proses edukasi terhadap masyarakat, yaitu melalui kegiatan pelatihan. Dengan dilakukan kegiatan pelatihan, selain diberikan berbagai macam materi oleh narasumber, masyarakat pun diajak untuk melakukan brainstrorming mengenai permasalahan yang dihadapi dan juga metode sharing terkait pengalaman di antara sesama peserta pelatihan dan juga dengan fasilitator pelatihan.

Bahan makanan pokok adalah bahan makanan paling utama dan dipandang sangat penting keberadaannya dan di makan oleh masyarakat dalam kehidupannya seharihari. Bahan makanan pokok ini umumnya menyediakan nutrisi yang cukup bagi tubuh manusia dan dijadikan sebagai sumber nutrisi utama untuk mempertahankan hidup sesuai dengan iklim serta keadaan di lingkungannya. Contoh makanan pokok yang biasa dikonsumsi oleh masyarakat Indonesia yaitu beras, kentang, ubi, jagung, dan sagu. Bahan makanan lainnya selain bahan makanan pokok disebut sebagai bahan makanan sampingan yang merupakan tambahan atau pelengkap dari bahan makanan pokok, yaitu bisa berupa lauk pauk ataupun berbagai jenis bahan makanan lainnya.

Biji hanjeli yang telah mengalami proses penyosohan disebut sebagai beras hanjeli memiliki karakteristik fisik dan kimia hampir sama dengan beras, sehingga sangat memungkinkan dapat digunakan sebagai alternative pengganti beras (Nurmala, dkk., 2015). Berikut ini merupakan Tabel perbandingan komposisi kimia beras dengan hanjeli: 


\begin{tabular}{|c|c|c|c|c|}
\hline Jurnal Penelitian \& PKM & Juli 2017 & Vol 4, No: 2 & Hal: $129-389$ & $\begin{array}{c}\text { ISSN } \\
2442-448 X(p), 2581-1126(e)\end{array}$ \\
\hline
\end{tabular}

Tabel 1. Komposisi Kimia Beras IR 36 dengan Hanjeli

\begin{tabular}{|l|c|c|}
\hline \multirow{2}{*}{ Komponen (\%) } & \multicolumn{2}{|c|}{ Jenis Beras } \\
\cline { 2 - 3 } & IR 36 & Hanjeli \\
\hline Kadar air & 12,58 & 11,46 \\
\hline Kadar lemak & 0,19 & 1,28 \\
\hline Kadar protein & 7,39 & 12,26 \\
\hline Kadar karbohidrat & 76,86 & 74,36 \\
\hline Abu & 0,20 & 0,65 \\
\hline
\end{tabular}

Sumber: Nurmala, dkk. (2015); Purwani, dkk. (2007)

Berdasarkan Tabel di atas menunjukkan bahwa beras hanjeli memiliki kandungan karbohidrat hampir sama dan kandungan protein lebih tinggi dibandingkan dengan beras IR 36. Hal ini menunjukkan bahwa hanjeli memiliki peluang besar untuk dikembangkan budidayanya di wilayah desa Karangasem dan Manggungan kecamatan Terisi.

Tanaman singkong yang dikenal juga dengan nama ubi kayu, ketela pohon, kaspe, dan lainnya berasal dari Brasil. Saat ini, tanaman singkong banyak dijumpai pada daerah dengan iklim dan tipe tanah sepanjang negara tropis. Singkong segar banyak mengandung air dan pati. Komposisi kimia dari tanaman singkong biasanya bervariasi tergantung dari varietas tanaman singkong itu sendiri dan juga adanya pengaruh faktor luar seperti iklim, kesuburan tanah, dan berbagai faktor luar lainnya.

Peningkatan kapasitas masyarakat melalui kegiatan penyuluhan, pelatihan dan pendampingan untuk menambah pengetahuan dan keterampilan masyarakat mengenai diversifikasi pengolahan pangan lokal sangat diperlukan untuk dapat memanfaatkan bahan pangan pokok non beras sebagai bahan baku olahan produk pangan. Baik untuk konsumsi keluarga maupun untuk produksi usaha, sehingga tercipta ketahanan pangan nasional yang berkelanjutan (sustainable).
Berdasarkan hal tersebut, pengetahuan dasar masyarakat mengenai bahan pangan pokok selain beras merupakan pengantar untuk dapat mengaplikasikannya menjadi berbagai produk olahan berbahan baku selain terigu dengan memanfaatkan tepung lokal. Hanjeli diperkenalkan kepada masyarakat sebagai pangan pokok selain beras yang memiliki potensi besar untuk dikembangkan di Desa Karangasem dan Manggungan, sedangkan singkong dan ubi jalar kuning merupakan potensi lokal yang belum termanfaatkan secara optimal menjadi produk pangan olahan pengganti terigu. Tepung hanjeli, singkong, dan ubi jalar kuning dapat digunakan sebagai bahan diversifikasi pangan olahan pengganti tepung terigu untuk produk kue kering, cake, brownies, dan mie.

\section{Simpulan:}

1. Beras hanjeli memiliki kandungan karbohidrat hampir sama $(74,36 \%)$ dan kandungan protein (12,26\%) lebih tinggi dibandingkan dengan beras IR 36.

2. Hanjeli diperkenalkan kepada masyarakat sebagai pangan pokok selain beras yang memiliki potensi besar untuk dikembangkan di Desa Karangasem dan Manggungan.

3. Singkong dan ubi jalar kuning merupakan potensi lokal yang belum 
termanfaatkan secara optimal menjadi produk pangan olahan pengganti terigu.

4. Tepung hanjeli, singkong, dan ubi jalar kuning dapat digunakan sebagai bahan diversifikasi pangan olahan pengganti tepung terigu untuk produk kue kering, cake, brownies, dan mie.

\section{Daftar Pustaka}

Belitz, H. D. and W. Grosch. 1999. Food Chemistry. Springer, Germany.

Bennion, M. 1980. The Science of Food. John Willey \& Sons, New York.

Departemen Kesehatan RI. 1995. Daftar Komposisi Zat Gizi Pangan Indonesia. Pusat Penelitian dan pengembangan Gizi, Jakarta.

Departemen Perindusrian. 1975. Pengolahan Jagung dan Tapioka. Proyek Bimbingan dan Pengembangan Industri Kecil, Jakarta.

Hubeis, M. 1984. Pengantar pengolahan Tepung Serealia dan Biji-bijian. Jurusan Teknologi Pangan dan Gizi. Fakultas Teknologi Pertanian. IPB, Bogor.
Kent, N. L. 1980. Technology of Cereals. Pergamon Press, Oxford.

Muchtadi, T. R. dan Sugiyono. 1989. Petunjuk Laboratorium Ilmu Pengetahuan Bahan Pangan, PAU Pangan dan Gizi Institut Pertanian Bogor, Bogor.

Nurmala, T., Warid Ali Qosim, Imas S. Setiasih, In-In hanidah. 2015. Adaptasi Enam Genotip Hanjeli Terseleksi pada Karakter Hasil dan Kualitas Tepung di Tiga Sentra Produksi Jawa Barat Untuk Mendukung Diversifikasi Pangan. Penelitian STRANAS. Dikti.

Pyke, M. Food Science and Technology. 1970. William Clowes and Sons Ltd., London.

Raharjo, ST. 2015. Assessment untuk Praktik Pekerjaan Sosial dan Kesejahteraan Sosial. Bandung: Unpad Press 2015. Dasar Pengetahuan Pekerjaan Sosial. Bandung: Unpad Press. 2015. Keterampilan Pekerjaan Sosial: Dasar-dasar. Bandung, Unpad Press.

Tull, A. 1987. Food and Nutrition. Oxford University Press, Oxford.

Winarno, F. G. 1988. Jagung. Badan Penelitian dan Pengembangan Pertanian, Jakarta 